Univerzitet u Beogradu
Poljoprivredni fakultet
Institut za poljoprivrednu tehniku
Naučni časopis
POLJOPRIVREDNA TEHNIKA
Godina XLV
Broj 4, 2020.
Strane: $29-39$

UDK: 621.1: 636.084.

Original scientific paper

Originalni naučni rad

doi:10.5937/POLJTEH2004029O

\title{
PHYSICAL PROPERTIES OF AFRICAN STAR APPLE FRUITS AND SEEDS
}

\author{
Augustine Onyekachi Igbozulike ${ }^{1^{*}}$, Gbenga Michael Oyinloye ${ }^{2}$, \\ Odirachukwu Onyejefu ${ }^{1}$, Cyprain Dirioha ${ }^{1}$, Patrick Dickson Diabana ${ }^{3}$ \\ ${ }^{1}$ Michael Okpara University of Agriculture, Umudike, Nigeria \\ ${ }^{2}$ Federal Polytechnic Nekede, Owerri, Nigeria \\ ${ }^{3}$ Yaba College of Technology, Lagos, Nigeria
}

\begin{abstract}
This research examines the physical properties of African star apple (Chrysophyllum albidum) fruits and seeds. The dimensions were measured with vernier calliper and the dimensional properties were computed using appropriate equations. The densities, porosity, angle of repose and coefficient of friction on three material surfaces were determined with standard methods from literature. The result of the study showed that the average major, intermediate and minor dimensions were $47.95 \mathrm{~mm}, 43.70 \mathrm{~mm}$ and $41.35 \mathrm{~mm}$ respectively for the fruits, and $26.05 \mathrm{~mm}, 15.12 \mathrm{~mm}$ and $6.07 \mathrm{~mm}$ respectively for the seeds. The volume, shape index and one thousand weight of fruits were obtained as $40.61 \mathrm{~mm}^{3}, 0.95$ and $48.34 \mathrm{~kg}$ respectively whereas those of the seeds were obtained as $1.69 \mathrm{~mm}^{3}, 0.95$ and $1.28 \mathrm{~kg}$ respectively. The true density, bulk density and porosity of the fruits were found to be $1710 \mathrm{~kg} / \mathrm{m}^{3}, 1550 \mathrm{~kg} / \mathrm{m}^{3}$ and 52.63 percent respectively, while that of the seeds were found to be $950 \mathrm{~kg} / \mathrm{m}^{3}, 570 \mathrm{~kg} / \mathrm{m}^{3}$ and 40.25 percent respectively. The sphericity obtained for the fruits and seeds were 0.94 and 0.55 , respectively. Angle of repose was found to be $3.02^{\circ}$ and $13.50^{\circ}$ for the fruits and seeds, respectively. Coefficients of friction on plywood, mild steel and galvanized steel were $0.30,0.24$ and 0.20 respectively, for the fruits and $0.52,0.46$ and 0.39 respectively for the seeds. The empirical data from this study will aid researchers in the design and development of postharvest systems for the African star apple fruits and seeds postharvest operations.
\end{abstract}

Key words: African star apple fruits and seeds, bulk and true densities, dimensions, postharvest.

*C Corresponding Author. E-mail: austin.igbozulike@gmail.com 


\section{INTRODUCTION}

The African star apple (Chrysophyllum albidum) is a tree crop that belongs to the family of Sapotaceae. The fruits and seeds are valued greatly in many African nations where the tree flourishes. The fruit contains higher quantity of ascorbic acid $(446 \pm 2.5$ $\mathrm{mg} / 100 \mathrm{~g}$ dry matter) compared to guava $(201.1 \pm 0.7 \mathrm{mg} / 100 \mathrm{~g}$ dry matter $)$ or orange $(28.89 \mathrm{mg} / 100 \mathrm{ml})$; and it also contains calcium, potassium, phosphorous, magnesium, tannins, flavonoids, terpenoids, and phytochemicals [1-4]. The nutritive value of the fruit makes it an excellent raw material for fruit jam, nectars, jelly and juice production [5-9]. According to [1], consumers of African star apple fruit have their blood sugar and cholesterol reduced. It was suggested that consumption of the fruit helps pregnant women for easy child delivery [10]. Some researchers [11] posit that the fruit is used to treat avitaminosis and dental decay in Benin republic. Each African star apple fruit has between $4-5$ seeds [12]. The seed contains $10.71 \%$ oil, $18.34 \%$ crude protein, $6.48 \%$ fat and $4.63 \%$ crude fibre $[13,14]$. The seed has potency in haemorrhoid and intestinal worm treatment [11].

Like many fruits, African star apple is a seasonal crop. The season spans between December and April [15]. The fruits are sold in markets and communities close to where they are grown. The fruit is yet to become an export commodity despite the potentials. The fruit suffers postharvest losses under ambient conditions [16, 17]. There is no standard storage and packaging systems for the fruits. This has further limited the commercialisation of the fruits. Therefore, there is need for the development of postharvest systems for the handling, processing and storage to guarantee availability of the fruits in and out of season. The design of such systems for postharvest operations of African star apple fruits and seed cannot be possible if their properties remain unknown. An attempt was made by [18] to investigate the properties of the seeds. However, their study failed to consider the properties of the fruits alongside.

The relevance of studying the physical properties of agricultural products cannot be overemphasized. As a result, many researchers have investigated the properties of various crops such as African breadfruit seed [19], yellow passion fruit seeds [20], kiwi fruits [21], Cucurbita moschata Duch. [22], date fruit varieties [23], groundnut pods and kernels [24], Canarium schweinfurthii Engl. fruits [25], Roselle calyxes [26], bottle gourd seeds [27], almond nut and kernel [28], wild mango fruit and nut [29], fluted pumpkin seed [30], African oil bean seed [31], Prosopis Africana seed [32], pistachio nuts and kernel [33], guan seed [34], among others. Apart from engineers, information on properties of biological materials is useful to scientists, processors and plant breeders [35].

Hence, the objective of this work was to determine the properties of the fruits and seeds of African star apple such as dimensions, densities, volume, porosity, angle of repose and coefficient of friction. 


\section{MATERIAL AND METHODS}

\section{Sample preparation}

A bulk sample of freshly harvested African star apple fruits were obtained from Ngwa road market, Aba in Eastern Nigeria.

The fruits were manually cleaned and sorted to ensure that only good quality fruits are used for the experiment. Two-third of the bulk fruit sample were ripped open to extract the seeds. The moisture content of the fruits and seeds were determined using oven drying method at $105^{\circ} \mathrm{C}$ for 24 hours. One hundred samples of fruits and seeds were randomly selected from the bulk sample for the measurement of axial dimensions. The dimensions were measured at moisture contents of 61.89 percent and 37.62 percent respectively for the fruits and seeds.

\section{Determination of the dimensions of the fruits and seeds}

The three principal axes, major (a), intermediate (b) and minor (c) dimensions of each fruit and seed were measured using digital vernier calliper (Mitutoyo, Japan) with an accuracy of $0.01 \mathrm{~mm}$. The geometric mean dimension $\left(D_{g}\right)$, arithmetic mean dimension $\left(D_{a}\right)$, sphericity $(\varphi)$ and square mean dimension $\left(D_{s}\right)$ were computed using Equations (1), (2), (3) and (4) thus [18, 32, 34]:

$$
\begin{aligned}
& D_{g}=(a b c)^{1 / 3} \\
& D_{a}=\frac{(a+b+c)}{3} \\
& \varphi=\frac{(a b c)^{1 / a}}{a} \\
& D_{s}=\left(\frac{a b+b c+a c}{3}\right)^{1 / 2}
\end{aligned}
$$

The shape index of the fruits and seeds was determined using the following Equation [36]:

$$
\text { Shape index }=\frac{a}{\sqrt{b c}}
$$

\section{Determination of the gravimetric properties}

One thousand weight of both the fruit and seed was determined using the method described by [37, 38] where 100 fruits and seeds were weighed separately with an electronic balance and multiplied by ten. The average mass of five replications was taken as the mean. 
The bulk density $\left(\rho_{b}\right)$ of the fruits and seeds was measured with the method used by [39]. The method involves weighing separately the fruits and seeds parked in containers of known volume. The sample was densely packed by gently tapping the container to allow the settling. Then the bulk density was computed as:

$$
\rho_{b}=\frac{\text { weight of material pocked }}{\text { kmown.whe }}
$$

The true densities $\left(\rho_{t}\right)$ of the fruits and seeds were determined using water displacement method. A sample was measured and the weight $\left(W_{s}\right)$ and number of samples $\left(n_{s}\right)$ in each experiment carefully noted. The sample was poured into a measuring cylinder of known volume, and the volume of water displaced was recorded. The true density was then computed thus:

$$
\rho_{t}=\frac{W_{s}}{V_{s}}
$$

The individual weight and volume of samples were determined from the measurements taken for true density. The porosity was calculated using the relationship between bulk and true densities [35]:

$$
p=\left(1-\frac{\rho_{b}}{\rho_{t}}\right) \times 100
$$

\section{Determination of the frictional properties}

The frictional properties which consist of the angle of repose and coefficient of frictions were studied for the seeds and fruits using the following methods.

\section{Angle of repose}

This was determined using a topless and bottomless cylinder as reported by [32, 40, 41]. The cylinder was placed over a smooth circular plate and filled with the fruits to a reasonable level. Then the cylinder was raised slowly allowing the fruits to flow down and form a natural cone. The height of the cone $(H)$ and the diameter $(D)$ were measured and the angle of repose calculated using the following Equation:

$$
\theta_{r}=\tan ^{-1}\left(\frac{2 H}{D}\right)
$$

\section{Coefficient of friction}

The static coefficient of friction was determined using an inclined plane [42]. The inclination of the test surface was gradually increased until the box just started to slide down and the angle of tilt $(\alpha)$ was read from the graduated scale attached to instrument. Three different material surfaces, namely, plywood, mild steel and galvanized steel were used to measure the friction coefficient of fruits and seeds on them. Five replications were taken for each test surface. 
For each replication, the sample in the container was emptied and refilled with new sample. The static coefficient of friction $\left(\mu_{\Xi}\right)$ was then calculated from Equation (10) given by [40]:

$$
\mu_{s}=\tan \alpha
$$

\section{RESULTS AND DISCUSSION}

\section{Dimensional properties}

The average values for the major, intermediate, minor, arithmetic mean, geometric mean and square mean dimensions of African star apple fruit are $47.95 \mathrm{~mm}, 43.70 \mathrm{~mm}$, $41.35 \mathrm{~mm}, 42.82 \mathrm{~mm}, 42.80 \mathrm{~mm}$, and $12.08 \mathrm{~mm}$ respectively, as shown in Table 1 .

The arithmetic and geometric mean dimensions are higher than the minor dimension but lower than the major and intermediate dimensions (Table 1). This follows the same trend for bottle gourd seeds [27].

Table 1. Physical properties of African star apple fruit

\begin{tabular}{lcccc}
\hline Properties & Minimum & Mean & Maximum & SD \\
\hline Major axis, $m m$ & 40.83 & 47.95 & 58.80 & 4.19 \\
Intermediate axis, $m m$ & 36.11 & 43.70 & 56.12 & 4.05 \\
Minor axis, $m m$ & 37.86 & 41.35 & 46.31 & 2.73 \\
Arithmetic mean dimension, $m m$ & 39.09 & 42.82 & 48.31 & 2.86 \\
Geometric mean dimension, $m m$ & 39.06 & 42.80 & 48.23 & 2.86 \\
Square mean dimension, $m m$ & 11.35 & 12.08 & 13.26 & 0.55 \\
Shape index, dimensionless & 0.92 & 0.95 & 0.96 & 0.01 \\
Sphericity, dimensionless & 0.92 & 0.94 & 0.95 & 0.01 \\
Unit volume, mm ${ }^{3}$ & 30.3 & 40.61 & 50.1 & 6.81 \\
Unit weight, $g$ & 38.5 & 48.92 & 60.4 & 6.72 \\
One thousand weight, $k g$ & 47.14 & 48.34 & 49.11 & 0.69 \\
SD is the standard deviation & & & &
\end{tabular}

The relationship between the dimension ratio $a / b, a / c, a / D_{g}$ and $a / D_{a}$ can be expressed as:

$$
a=1.10 b=1.16 c=1.12 D_{g}=1.12 D_{a}
$$

This indicates that the intermediate, minor, geometric mean and arithmetic mean dimensions have positive relation with the major axis.

The mean values of African star apple shape index and sphericity are 0.95 and 0.94 respectively. 
The sphericity value falls within the range of $0.32-1.00$ for most agricultural materials [35]. The value of the sphericity that is closer to 1.00 shows that the fruit has high tendency to roll than slide [29, 41].

\section{Dimensions of the African star apple seed}

The average values for the major, intermediate, minor, arithmetic mean, geometric mean and square mean dimensions of African star apple seeds were $26.05 \mathrm{~mm}, 15.12$ $\mathrm{mm}, 6.07 \mathrm{~mm}, 15.63 \mathrm{~mm}, 14.91 \mathrm{~mm}$, and $6.06 \mathrm{~mm}$ respectively, as shown in Table 2 . The shape index and sphericity were obtained as 0.95 and 0.55 , respectively. Unlike the fruit, the African star apple seed will not roll easily because of its relative low sphericity value of 0.55 .

Table 2. Physical properties of African star apple seed

\begin{tabular}{lcccc}
\hline Properties & Minimum & Mean & Maximum & SD \\
\hline Major axis, mm & 21.81 & 26.05 & 31.64 & 1.81 \\
Intermediate axis, mm & 12.55 & 15.12 & 17.78 & 1.09 \\
Minor axis, mm & 8.49 & 6.07 & 10.69 & 0.59 \\
Arithmetic mean dimension, $m m$ & 17.49 & 15.63 & 18.83 & 0.93 \\
Geometric mean dimension, $m m$ & 15.81 & 14.91 & 17.03 & 0.68 \\
Square mean dimension, $m m$ & 6.50 & 6.06 & 6.84 & 0.23 \\
Shape index, dimensionless & 1.02 & 0.95 & 1.12 & 0.05 \\
Sphericity, dimensionless & 0.58 & 0.55 & 0.63 & 0.02 \\
Unit volume, mm $^{3}$ & 1.85 & 1.69 & 1.99 & 0.09 \\
Unit weight, $g$ & 1.33 & 0.70 & 1.70 & 0.21 \\
One thousand weight, $k g$ & 1.30 & 1.28 & 1.32 & 11.35 \\
\hline
\end{tabular}

$S D$ is the standard deviation

\section{Gravimetric and frictional properties of the fruits and seeds}

The average values of the bulk and true densities of African star apple fruits were found to be $1550 \mathrm{~kg} / \mathrm{m}^{3}$ and $1710 \mathrm{~kg} / \mathrm{m}^{3}$, respectively (Table 3). The bulk and true densities of the fruit are higher than that of the seeds average values found to be 570 $\mathrm{kg} / \mathrm{m}^{3}$ and $950 \mathrm{~kg} / \mathrm{m}^{3}$ respectively (Table 4). The densities are in the range obtained for the seeds at 8.49 percent moisture content dry basis [18]. The true density of the fruit is higher than that of Pistachio kernel $\left(1082.73-1087.98 \mathrm{~kg} / \mathrm{m}^{3}\right)$ and Pistachio nuts $\left(1180.75-1210.50 \mathrm{~kg} / \mathrm{m}^{3}\right)$ as reported by [33].

The bulk density of the seed is close to the values of Pistachio bulk density, 465.38$576.20 \mathrm{~kg} / \mathrm{m}^{3}$ [33] and higher than that of groundnut, $479.28 \mathrm{~kg} / \mathrm{m}^{3}$ [43].

The porosity of the fruit, which is dependent on the bulk and density densities, was higher than that of the seed. The average value of the fruit porosity was obtained as 52.63 percent (Table 3 ) whereas that of the seed is 40.25 percent (Table 4 ). 
The porosities of both the fruit and the seed are within the range of porosity of karingda seed, 40.7 - 57.6 percent, reported by [42]. The porosity is important in designing drying, packaging and storage systems for the product. The angle of repose, which is the angle at which the product will stand when piled, was obtained as $3.02^{\circ}$ and $13.50^{\circ}$ respectively, for the fruit and the seed (Tables 3 and 4). These values are below the highest possible angle of repose of $45^{\circ}$ for most agricultural products [35].

The fruit's coefficient of friction was found to be $0.30,0.24$ and 0.20 on plywood, mild steel and galvanised steel surfaces, respectively (Table 3).

The coefficient of friction of the fruit on galvanized steel is similar to that of Garcinia kola seeds (0.20) on galvanized steel surface [41] and the value on plywood compares well with the value obtained for oilseed bean on glass (0.29) as reported by [44].

Table 3. Gravimetric and frictional properties of African star apple fruit

\begin{tabular}{lcccc}
\hline Properties & Minimum & Mean & Maximum & $S D$ \\
\hline Bulk density, $\mathrm{kg} / \mathrm{m}^{3}$ & 1200 & 1550 & 1800 & 0.20 \\
True density, $\mathrm{kg} / \mathrm{m}^{3}$ & 1380 & 1710 & 1940 & 0.18 \\
Angle of repose, degree & 2.87 & 3.02 & 3.20 & 0.12 \\
Porosity, \% & 51.04 & 52.63 & 53.12 & 0.61 \\
Coefficient of friction on: & & & & \\
Plywood & 0.28 & 0.30 & 0.31 & 0.004 \\
Mild steel & 0.23 & 0.24 & 0.26 & 0.007 \\
Galvanized steel & 0.19 & 0.20 & 0.22 & 0.008 \\
\hline
\end{tabular}

$S D=$ standard deviation

Table 4. Gravimetric and frictional properties of African star apple seed

\begin{tabular}{lcccc}
\hline Properties & Minimum & Mean & Maximum & $S D$ \\
\hline Unit weight, $g$ & 1.33 & 0.70 & 1.70 & 0.21 \\
One thousand weight, $\mathrm{kg}$ & 1.30 & 1.28 & 1.32 & 11.35 \\
Bulk density, $\mathrm{kg} / \mathrm{m}^{3}$ & 560 & 570 & 590 & 0.01 \\
True density, $\mathrm{kg} / \mathrm{m}^{3}$ & 970 & 950 & 990 & 0.01 \\
Angle of repose, degree & 15.15 & 13.50 & 17.10 & 1.02 \\
Porosity, \% & 42.71 & 40.25 & 44.83 & 0.43 \\
Coefficient of friction on: & & & & \\
Plywood & 0.52 & 0.50 & 0.54 & 0.02 \\
Mild steel & 0.46 & 0.44 & 0.48 & 0.01 \\
Galvanized steel & 0.39 & 0.34 & 0.42 & 0.03 \\
SD Standard deviation & & & &
\end{tabular}

$S D=$ Standard deviation 
The coefficient of friction of the African star apple seed was found to be 0.50, 0.44 and 0.34 on plywood, mild steel and galvanised steel surfaces, respectively (Table 4). It was observed that these values are higher than that of the fruit on the same material surfaces. These data are valuable for the design of hoppers, conveying systems, and storage systems for the product.

\section{CONCLUSIONS}

The following conclusions were drawn from the investigation on the physical properties of African star apple fruits at moisture content of 61.89 percent (wet basis) and African star apple seeds at moisture content of 37.62 percent (wet basis). The average characteristic dimensions - major, intermediate and minor axes - of the fruit were $47.95 \mathrm{~mm}, 43.70 \mathrm{~mm}$ and $41.35 \mathrm{~mm}$, respectively, whereas those of the seed were $26.05 \mathrm{~mm}, 15.12 \mathrm{~mm}$ and $6.07 \mathrm{~mm}$, respectively. The bulk and true densities were found to be $1550 \mathrm{~kg} / \mathrm{m}^{3}$ and $1710 \mathrm{~kg} / \mathrm{m}^{3}$ for the fruits, and $570 \mathrm{~kg} / \mathrm{m}^{3}$ and $950 \mathrm{~kg} / \mathrm{m}^{3}$ for the seeds, respectively. The porosity was found to be 52.63 percent for the fruit and 40.25 percent for the seed. Angle of repose was obtained as $3.02^{\circ}$ for the fruit and $13.50^{\circ}$ for the seed. These empirical data for the various properties of African star apple fruit and seed will be useful in designing postharvest systems that will add value to the African star apple fruits and seeds.

\section{REFERENCES}

[1] Cangao, C. 2011. African indigenous fruits with potential health benefits http://www.itfnet.org/v1/2011/12/african-indigenous-fruits-with-potential-health-benefits (accessed September 30, 2020).

[2] Jawaheer, B., Goburdhun, D. and Ruggoo, A. 2003. Effect of processing and storage of guava into jam and juice on the ascorbic acid content. Plant F. for Human Nutrition, 58(3), pp. 1-12.

[3] Kabasakalis, V., Siopidou, D. and Moshatou, E. 2000. Ascorbic acid content of commercial fruit juices and its rate of loss upon storage. Food chemistry, 70(3), 325-328.

[4] Edem, D.O., Eka, O.U. and Ifon, E.T. 1984. Chemical evaluation of nutritive value of the fruit of African star apple (Chrysophyllum albidum). Food chemistry, 14(4), 303-311.

[5] Aworh, O.C. 2015. Promoting food security and enhancing Nigeria's small farmers' income through value-added processing of lesser-known and under-utilized indigenous fruits and vegetables. Food Research International, 76(4), pp. 986-991.

[6] Ureigho, U.N. and Ekeke, B.A. 2010. Nutrient values of Chrysophyllum albidum Linn African star apple as a domestic income plantation species. African Research Review, 4(2), pp. 50-56.

[7] ICRAF. 2007. Chrysophyllum albidum. Int. Centre for Res. in Agroforestry. Kenya. 3p.

[8] Falade, K. 2001. Drying, sorption, sensory and microbiological characteristics of osmotically dried African star apple and African wild mango. PhD dissertation, University of Ibadan, Ibadan, Nigeria

[9] Okafor, J.C. 1981. Horticulturally promising indigenous wild plant species of the Nigerian forest zone. African Symposium on Horticultural Crops, 123(6), pp. 165-176.

[10] National Research Council (2008). Lost crops of Africa. Volume III: Fruits, Washington, D.C.: The National Academic Press. pp. 319 - 321. 
[11] Houessou, L.G., Lougbegnon, T.O., Gbesso, F.G., Anagonou, L.E. and Sinsin, B. 2012. Ethno-botanical study of the African star apple (Chrysophyllum albidum G. Don) in the Southern Benin (West Africa). Journal of Ethnobiology and Ethnomedicine, 8(1), 40.

[12] Keay, R.W.J. 1989. Trees of Nigeria. Clarendon Press.

[13] Adebayo, S.E., Orhevba, B.A., Adeoye, P.A., Musa, J.J. and Fase, O.J. 2012. Solvent extraction and characterization of oil from African star apple (Chrysophyllum albidum) seeds. Academic Research International, 3(2), pp. 178-183.

[14] Odo, M.O., Ngele, S. and Okezue, I.E. 2005. Evaluation of nutritional composition and anti-nutrients in African white star apple (Chrysophyllum abidum) seed. Nigerian Food Journal, 23(1), pp. 252-255.

[15] Isah, A.P., Danladi, Y., and Ejike, O. J. 2013. Proximate composition and some functional properties of flour from the kernel of African star apple (Chrysophyllual albidum). Int J Agric Pol Res, 1, pp.62-66.

[16] Bello, F.A. and Henry, A.A. 2015. Storage effects and the postharvest quality of African star apple fruits (Chrysophyllum africanum) under ambient conditions. African Journal of Food Science \& Technology, 6(1), pp. 35-43.

[17] Ugwu, J.A. and Umeh, V.C. 2015. Assessment of African star apple (Chrysophyllumalbidum) fruit damage due to insect pests in Ibadan, Southwest Nigeria. Research Journal of Forestry, 9(3), pp. 87-92.

[18] Oyelade, O.J., Odugbenro, P.O., Abioye, A.O. and Raji, N.L. 2005. Physical properties of African star apple seeds. Journal of Food Engineering, 67(4), 435-440.

[19] Obi, O.F., and Okechukwu, M.E. (2020). Parboiling duration effects on physical properties of African breadfruit seed. Ag. Engineering International: CIGR Journal, 22(2), pp. 186-193.

[20] de Araujo, M.E.V., Barbosa, E.G., de Oliveira, A.C.L., Milagres, R.S., de Carvalho Pinto, F.D.A., and Corrêa, P.C. (2020). Physical properties of yellow passion fruit seeds (Passiflora edulis) during the drying process. Scientia Horticulturae, 261, 109032.

[21] Vahedi Torshizi, M., Khojastehpour, M., Tabarsa, F., Ghorbanzadeh, A., and Akbarzadeh, A. (2020). Investigation of Physical Properties Changes of Kiwi Fruit during Different Loadings, Storage, and Modeling with Artificial Neural Network. International Journal of Fruit Science, pp. 1-19.

[22] Singh, A., and Kumar, V. 2020. Cultivars Effect on the Physical Characteristics of Pumpkin (Cucurbita moschata Duch.) Seeds and Kernels. J. Inst. Eng. India Ser. A https://doi.org/10.1007/s40030-020-00460-6

[23] Abd El-Raouf, A.E R., Ahmed-PTPE, L. W. E., \& EEPP, I. (2019). Mathematical model for some physical characteristics of yellow and red date fruits varieties. Agricultural Engineering International: CIGR Journal, 21(3), pp. 234-241.

[24] Muhammad, A.I., Ahmad, R.K. and Lawan, I. 2017. Effect of moisture content on some engineering properties of groundnut pods and kernels. Agric Eng Int: CIGR Journal, 19(4), pp. 200-208.

[25] Ehiem, J.C., Ndirika, V.I.O. and Onwuka, U.N. 2016. Effect of moisture content on some physical properties of Canarium schweinfurthii Engl. fruits. Res.Agr.Eng., 62(4), 162-169.

[26] Aregbesola, O.A., Faborode, M.O. and Ezeokoli, O.I. 2016. Engineering properties of Roselle (Hibiscus sabdariffa) calyxes. Agric Eng Int: CIGR Journal, 18(3), 225-232.

[27] Pradhan, R.C., Said, P.P. and Singh, S. 2013. Physical properties of bottle gourd seeds. Agricultural Engineering International: CIGR Journal, 15(1), pp. 106-113.

[28] Mirzabe, A.H, Khazaei, J., Chegini, G.R. and Gholami, O. 2013. Some physical properties of almond nut and kernel and modeling dimensional properties. Agricultural Engineering International: CIGR Journal, 15(2), pp. 256-265.

[29] Ehiem, J.C. and Simonyan, K.J. 2012. Physical properties of wild mango fruit and nut. International Agrophysics, 26(1): pp. 95-98. 
[30] Igbozulike, A.O. and Amamgbo, N. 2019. Effect of moisture content on physical properties of fluted pumpkin seeds. Journal of Biosystems Engineering, 44; pp. 69-76.

[31] Asoegwu, S.N., Ohanyere, S.O., Kanu, O.P. and Iwueke, C.N. 2006. Physical properties of African oil bean seed (Pentaclethra macrophylla). Agricultural Engineering International: CIGR Journal.

[32] Akaaimo, D.I. and Raji, A.O. 2006. Some physical and engineering properties of Prosopis africana seed. Biosystems Engineering, 95(2), pp. 197-205.

[33] Kashaninejad, M., Mortazavi, A., Safekordi, A. and Tabil, L.G. 2006. Some physical properties of Pistachio (Pistacia vera L.) nut and its kernel. J. of Food Eng., 72(1), 30-38.

[34] Aviara, N.A, Gwandzang, M.I and Haque, M.A. 1999. Physical properties of guna seeds. Journal of Agricultural Engineering Research, 73(2), pp. 105-111.

[35] Mohsenin, N.N. 1986. Physical properties of Plant and Animal Materials, second ed. Gordon and Breach Science Publishers, New York.

[36] Bahnasawy, A.H., El-Haddad, Z.A., El-Ansary, M.Y. and Sorour, H.M. 2004. Physical and mechanical properties of some Egyptian onion cultivars. Journal of Food Engineering, 62(3), pp. 255-261.

[37] Nalladurai, K., Alagusundaram, K. and Gayathri, P. 2002. PH—Postharvest Technology: Airflow resistance of paddy and its byproducts. Biosystems engineering, 83(1), 67-75.

[38] Varnamkhasti, M.G, Mobli, H, Jafari, A, Keyhani, A.R, Soltanabadi, M.H, Rafiee, S. and Kheiralipour, K. 2008. Some physical properties of rough rice (Oryza Sativa L.) grain. Journal of Cereal Science, 47(3), pp. 496-501.

[39] Ndirika, V.I.O., and Oyeleke, O.O. 2006. Determination of selected physical properties and their relationships with moisture content for millet (Pennisetum glaucum L.). Applied Engineering in Agriculture, 22(2), pp. 291-297.

[40] Razavi, S.M. and Milani, E. 2006. Some physical properties of the watermelon seeds. African Journal of Agricultural Research, 1(3), pp. 065-069.

[41] Igbozulike, A.O. and Aremu, A.K. 2009. Moisture dependent physical properties of Garcinia kola seeds. Journal of Agricultural Technology, 5(2), pp. 239-248.

[42] Suthar, S.H, and Das, S.K. 1996. Some physical properties of karingda [Citrullus lanatus (Thumb) Mansf] seeds. Journal of Agricultural Engineering Research, 65(1), pp. 15-22.

[43] Davies, R.M. 2009. Some physical properties of groundnut grains. Research Journal of Applied Sciences, Engineering and Technology, 1(2), pp. 10-13.

[44] Oje, K. and Ugbor. E.C. 1991. Some physical properties of oil bean seed. Journal of Agricultural Engineering Research, 50(4), pp. 305-313.

\title{
FIZIČKE OSOBINE PLODA I SEMENA JABUKE AFRIČKA ZVEZDA
}

\author{
Augustine Onyekachi Igbozulike ${ }^{1}$, Gbenga Michael Oyinloye ${ }^{2}$, \\ Odirachukwu Onyejefu ${ }^{1}$, Cyprain Dirioha ${ }^{1}$, and Patrick Dickson Diabana ${ }^{3}$ \\ ${ }^{1}$ Michael Okpara University of Agriculture, Umudike, Nigeria \\ ${ }^{2}$ Federal Polytechnic Nekede, Owerri, Nigeria \\ ${ }^{3}$ Yaba College of Technology, Lagos, Nigeria
}

Sažetak: Ovo istraživanje prikazuje fizičke osobine plodova i semena jabuke Afrička zvezda (Chrisophillum albidum). Dimenzije su merene preciznim pomičnim merilom (nonijus-mikrometar). Karakteristične dimenzije izračunate pomoću odgovarajućih relacija i jednačina. 
Zapremina, poroznost, ugao nagiba i koeficijent trenja po podlozi za tri površine različitih materijala utvrđeni su standardnim metodama iz literature. Rezultat studije je pokazao da su prosečne velike, srednje i male dimenzije jabuke bile: $47,95 \mathrm{~mm}, 43,70$ $\mathrm{mm}$ i $41,35 \mathrm{~mm}$ za plodove, odnosno $26,05 \mathrm{~mm}, 15,12 \mathrm{~mm}$ i $6,07 \mathrm{~mm}$ za seme jabuke. Gustina, indeks oblika i težina hiljadu plodova, dobijeni su kao 40,61 $\mathrm{mm}^{3}, 0,95$ i 48,34 $\mathrm{kg}$, dok su semena dobijena kao $1,69 \mathrm{~mm}^{3}, 0,95$ i $1,28 \mathrm{~kg}$, retrospektivno. Utvrđeno je da su stvarna gustina, zapreminska težina i poroznost plodova $1710 \mathrm{~kg} / \mathrm{m}^{3}, 1550 \mathrm{~kg} / \mathrm{m}^{3}$, odnosno 52,63\%, dok je određeno da je gustina semena $950 \mathrm{~kg} / \mathrm{m}^{3}, 570 \mathrm{~kg} / \mathrm{m}^{3}$ i 40,25\% retrospektivno.

Dobijena sferičnost plodova i semena jabuke iznosila je 0,94 , odnosno 0,55 . Utvrđeno da je ugao mirovanja (nema kotrljanja) za plodove $3,02^{\circ}$, odnosno za seme $13,50^{\circ}$. Koeficijenti trenja po šper ploči, mekanom čeliku i pocinkovanom čeliku su vrednosti 0,$30 ; 0,24$, i 0,20 za plodove, odnosno 0,$52 ; 0,46$ i 0,39 za semena jabuke.

Empirijski podaci iz ove studije pomoći će istraživačima u dizajnu i razvoju sistema čuvanja za plodove i semena jabuke Afrička zvezda (Chrisophillum albidum) posle berbe.

Ključne reči: Plodovi i semena jabuke Afrička zvezda, zapremina i stvarna gustina, dimenzije, naknadna berba.

Prijavljen: Submitted 02.10.2020.

Ispravljen Revised:

Prihvaćen

Accepted:

26.10.2020. 